\title{
Influence of the design on slope stability in solid waste landfills
}

\author{
Francisco J. Colomer-Mendoza*, Joan Esteban-Altabella, Ferran García-Darás, \\ Antonio Gallardo-Izquierdo
}

Universidad Jaume I, Castellón, Spain

\section{Email address:}

fcolomer@uji.es (F. J. Colomer-Mendoza)

\section{To cite this article:}

Francisco J. Colomer-Mendoza, Joan Esteban-Altabella, Ferran García-Darás, Antonio Gallardo-Izquierdo. Influence of the Design on Slope Stability in Solid Waste Landfills, Earth Science. Vol. 2, No. 2, 2013, pp. 31-39. doi: 10.11648/j.earth.20130202.12

\begin{abstract}
This paper presents, firstly, the influence of the geometry of a slope in the safety factor (SF). In order to do this, the SF is compared among three types of slopes: with berms every $7 \mathrm{~m}$ high and a dam at the toe, without berms and with a dam at the toe, and without berms nor dams. It was observed that, for the same inclination, the berms do not significantly influence the stability. However, the construction of an earth dam at the base increases safety, especially with little height and slope in waste with poor mechanical properties. On the other hand, a set of diagrams to learn, quickly and easily, the safety factor of a landfill slope has been developed. Thus, this set of diagrams allows calculations from the SF height (from 17 to $80 \mathrm{~m}$ ) and slope inclination (from $45^{\circ}$ to $14^{\circ}$ ) with values of effective cohesion of the waste ( $\mathrm{C}^{\prime} \mathrm{o}$ ) from 1 to $3 \mathrm{t} / \mathrm{m}^{2}$ and effective friction angle $\left(\Phi^{\prime}\right)$ of $10^{\circ}$ to $25^{\circ}$.
\end{abstract}

Keywords: Landfill, Slope, Mechanical Properties, Safety Factor, Stability, Slide

\section{Introduction}

Landfill is critical to most waste management strategies, because it is the simplest, cheapest and most cost-effective method of disposing waste. Although in the future, waste minimization and recycling programs will reduce waste volumes, and other waste treatment options may be developed, at the end of the day landfills will still be required to accommodate residual waste [1].

Due to environmental and health risks from landfills, a significant number of nations and international organizations (EU, World Bank, UN, etc.) have developed, in recent decades, specific rules for the location, design, operation and control of landfills. This legislation looks forward to minimizing the environmental impact generated by the landfills. However, before the application of different regulations, many landfills were built totally uncontrolled, with no corrective or protective measures, with little compaction, without gas extraction systems or leachate disposal. These dumps were closed and most of them have not been adapted to the legislation of each country.

This work is based on sanitary landfills. The term "Sanitary landfill" is widely used in many developing countries as a way to describe the permitted and controlled deposit of solid waste, however, in some places this term is used to define any type of landfill [2], even open dumps, which have no previous engineering design. This lack of adequate design and management method can cause accidents when conditions exceed a certain threshold.

Geotechnical accidents occurred in landfills may be due to many causes, or, in most cases, interactions between them. An accident can result from the accumulation of leachates at the bottom, excessive height and inclination in the slope, accumulation of biogas, from poor waste compaction, excessive slope of the underlying terrain and many other causes. The consequences of such accidents are often dependent on the magnitude of the accident and can cause serious health problems, substantial environmental impact and even property damage and deaths. In many cases, accidents are due to poor waste management. But the cause of a significant number of cases has been the lack of good mechanical properties, physicochemical and biological waste and its evolution over time (heterogeneity, settlements, fermentation, biogas and leachate generation, etc.). There is now a growing participation of specialists, from research and experimental studies, and published data on physical and geotechnical properties of waste (Table 1). Despite this, their geotechnical behavior is very heterogeneous, complex and, to some extent, still unknown. 
Table 1. Comparison of geotechnical properties of some waste from landfills according different authors.

\begin{tabular}{|c|c|c|}
\hline $\begin{array}{l}\text { Referencia } \\
(1 \mathrm{t} / \mathrm{m} 2=9.81 \mathrm{kPa})\end{array}$ & $C^{\prime} 0(t / m 2)$ & $\Phi^{\prime}\left({ }^{\circ}\right)$ \\
\hline [18] & $0-2.86$ & $15-42$ \\
\hline [19] & 1.02 & 23 \\
\hline [20] & $1.52-1.84$ & $15-22$ \\
\hline [21] & $1.60-2.40$ & $21-22$ \\
\hline [22] & $1.02-2.34$ & $24-42$ \\
\hline [23] & 2.34 & 24 \\
\hline [24] & 0 & 41 \\
\hline [25] & 6.7 & $15-25$ \\
\hline [26] & 2.4 & $10-30$ \\
\hline [27] & 2.9 & 22 \\
\hline [28] & $6.7-6.8$ & 23 \\
\hline [29] & 2 & 30 \\
\hline [30] & 0.75 & \\
\hline [31] & $0-2$ & $16-26$ \\
\hline [32] & 1.92 & 20 \\
\hline [33] & $0.41-0.51$ & $33-36$ \\
\hline [34] recompacted waste & 2.24 & 17 \\
\hline [34] simply extracted & 2.45 & 18 \\
\hline [5] & 2.54 & 35 \\
\hline [35] & 0.51 & 28 \\
\hline [7] & 4.38 & 31 \\
\hline [36] & 7.95 & 23 \\
\hline [37] & $2.15-4.32$ & 18.4 \\
\hline [38] & $1.02-1.22$ & $33-38$ \\
\hline [39] & $3.16-6.53$ & $26-30$ \\
\hline [40] & $0.02-2.65$ & $10-48$ \\
\hline [41] & $3.67-4.69$ & $36-46$ \\
\hline
\end{tabular}

The assessment of waste mass stability is a critical step in reducing the risk for the landfill operatives and the general public. Major slope failures can occur, as demonstrated by the July 10, 2000, Payatas Landfill Failure, in Quezon City, the Philippines [3], and the subsequent slide at the Bandung landfill in Indonesia [4]. In both of these cases, major failures led to significant loss of life. The largest slope failure in a North American municipal solid waste (MSW) landfill occurred on March 9, 1996 and involved 1.2 Mm3 of waste, providing the industry with knowledge of the operation, expansion, and stability of existing landfill slopes. One of the largest, previous waste slope failures involved 500,000 m3 in Maine, USA [5]. A number of researchers have concluded that major landfill failures are usually associated with site-specific factors such as excessive pore pressures or weak foundation soils $[6,7,8]$. Considerable effort has been focused on ensuring design integrity of slopes for sanitary landfills in the developed world, though slope instability has still occurred. To evaluate the stability of slopes, it is required to have an accurate and reliable estimate of the in situ shear strength of the waste [8].

Selection of appropriate shear strength parameters is a key aspect of the slope stability analysis, which relies on information on waste composition, particle size, degree of degradation, and moisture content. With estimates of waste shear strength parameters, one can provide the landfill operator with information on the critical slope angles, slope heights, and leachate levels to operate the site in a safe manor [8]. So, many factors can trigger waste-body instability [9]; however, a high leachate level is undoubtedly one of the most important [10].

One of the most difficult tasks for evaluating slope stability in MSW landfills includes accurate determination of shear strength parameters and weight units for waste Although significant scatter exists in these parameters due to the natural characteristics of MSW, considerable efforts have been made toward finding generic rules for these parameters. These findings are especially useful when there is lack of information on the site. Moreover, the lower and upper bounds of these published values can be used to obtain the range of safety factors for slope stability analyses in MSW landfills [11].

On the other hand, the results of Choudhury and Savoikar [12] indicated that the seismic stability of waste fills depends primarily on the dynamic properties, height of the fill and the characteristics of the design and bedrock motions. Influence of foundation types, height and stiffness of MSW landfills and seismic base accelerations on the seismic responses in terms of surface accelerations, normalized stresses (i.e., shear stress/effective vertical stress) and spectral amplification were evaluated in their works too. The results showed that height and stiffness of landfills, type of foundation and amount of seismic base acceleration and period play an important role in evaluating the seismic responses of MSW landfills [12].

According to Feng and Gao [13], the landfill can be divided into three discrete parts: an active wedge lying on the back slope (resting on either liner surfaces or previously placed waste) that tends to cause failure, a passive wedge 
lying on the landfill's foundation soil or liner system that tends to resist failure and a retaining wall at the toe berm of the landfill that improves the stability of the waste mass.

Therefore, this paper aims to assess how construction of berms and a dam at the toe affect the stability of the slope (the value of SF). This paper also presents a set of diagrams for easy and quick estimation of the SF of a slope.

\section{Geotechnical Risks}

According to the design of landfills, the factors that may affect safety or stability of the landfill are the topography and morphology of the initial site. Landfills with higher risk of sliding are placed on hillsides and valleys, in which the inclination of the hillside and the friction coefficient between: waste-impermeable sheet and sheet-waterproof floor have to be considered. Likewise, when a previous design does not exist, the waste is deposited anarchically and slopes increase their height in an uncontrolled way, without taking into account the mechanical properties of the waste, which involves an evident risk. Furthermore, biogas and absence of leachate drainage systems generate pressures within the waste mass which decrease its stability, thereby increasing the likelihood of a landslide. All the above parameters can be combined together and cause an accident with serious consequences. Therefore, it appears necessary to assess the geotechnical risk involved in any landfill.

One of the structural failures that can occur in a landfill is due to incorrect geometrical design of the slopes due to low safety factor (SF). Mechanical and physical properties of the waste to be deposited must be known to calculate the SF of the slope in a landfill. Among these properties is the density, humidity, etc. Density $(\gamma)$ depends directly on the composition, moisture and the degree of compaction and is one of the needed parameters to determine the stability of a slope. The other required parameters are the effective cohesion $\left(C^{\prime} \mathrm{o}\right)$ and the effective friction angle $\left(\Phi^{\prime}\right)$.

In order to know $C^{\prime} \mathrm{o}$ and $\Phi$ ', laboratory tests are used. Due to the heterogeneous composition of the waste material (plastic, fabric, organic material, paper, metal, etc.) and particle size (from small pieces of organic material to large cardboard or plastic film type) the results are very heterogeneous and differ widely between different trials, even within the same landfill, various tests can provide different values. Furthermore, depending on the depth to which the test is carried out, the variation of density is much greater than in soils. Waste lifespan also has an influence, for example fermentable organic matter is degraded forming liquids and other simpler compounds. On the other hand, extracted samples modify the properties with respect to their state at the dump, since in the extraction process, the samples suffer disintegration. When samples are received in the laboratory they are compacted in the test kit for testing. Therefore, the results obtained in the test will differ from the original [14]. Thus, various geotechnical tests conducted around the world have provided very different values. Values of C'o have a range from $0 \mathrm{t} / \mathrm{m}^{2}$ [15] to $12.64 \mathrm{t} / \mathrm{m}^{2}[16]$ and the values of $\Phi^{\prime}$ have ranges from $0^{\circ}$ [17] to $53^{\circ}$ [15]. Other collected data are shown in Table 1.

If the landfill rules of various countries are analyzed it can be seen that most regulations provide for maximum inclination of the slopes of $1 \mathrm{~V}: 2.5 \mathrm{H}$ (World Bank) to $1 \mathrm{~V}$ : $4 \mathrm{H}$ (Canada). The SF of slopes with these inclinations is usually acceptable but depends on the properties of the waste, climatic conditions and altitude [42]. Generically speaking, the legislation states that an appropriate SF, to ensure the stability of a slope to avoid slide, can vary between 1.3 and $1.5[43,44]$. Nevertheless, The C'o of any material decreases significantly when the material is saturated. Moreover, in conditions of saturation, pore pressure increases significantly which decreases the SF and therefore, stability. The same applies to the waste, which is not always taken into account in the design and operation.

Rainwater infiltrates in waste mass and percolates to the lower layers and accumulates at the base of the landfill. This accumulation of leachate causes saturation at the bottom and a significant decrease in the C'o of the waste and, if there is no drainage, a significant increase in pore pressure. The effect of this decrease in C'o and the increase in pore pressure can cause a loss of stability and the consequent slide of the slope. According to soil mechanic equations, if pore pressure increases due to leachate, and gas accumulation, and diminished C'o, then the shear stress also decreases.

\section{Material and Methods}

Because of the risk involved in this type of installations, there is a need for the geotechnical stability of the slopes of the landfill to be high, even in high humidity conditions in the waste mass. As seen before, the mechanical properties of the residues are very variable and unpredictable a priori, so that it is preferable to adopt a minimum value of effective cohesion and effective friction angle. Consequently, the results will be safe.

The calculation of slope stability was performed using the software "Slope Stability" designed by professor Rechea from the School of Architecture of the Polytechnic University of Valencia (Spain), developed from the modified Bishop method. This academic software was developed and validated by the doctoral thesis of F. Zapata (2003) [45]. Calculations of diagrams are recently based on software Slope/W 2012® [46]. In the first set of diagrams, a 10 $\mathrm{m}$ high lower dam forming a vessel to be filled with waste was designed. When the vessel is full, a second dam is constructed $7 \mathrm{~m}$ high and is refilled. And so on, until the maximum height is reached (Figure 1). The second case consists of the same slope height and inclination, but without berms and dams at the base, and the third case was a slope with a dam on the base but without berms. So, on the one hand, there are six graphs that detail the variation of SF with respect to the height of the slope. The inclinations are $45^{\circ}$ (Figure 2a), 33 ${ }^{\circ}$ (Figure 2b), $27^{\circ}$ (Figure 2c), $23^{\circ}$ (Fig- 
ure $2 \mathrm{~d}$ ), $19^{\circ}$ (Figure 2e) and $14^{\circ}$ (Figure 2f). The height of the slopes has varied from 17 to $65 \mathrm{~m}$. The mechanical properties of the first set are the following: $\gamma=0.9 \mathrm{t} / \mathrm{m} 3$, $\mathrm{C}^{\prime} \mathrm{o}=1 \mathrm{t} / \mathrm{m} 2$ and $\Phi^{\prime}=14^{\circ}$.

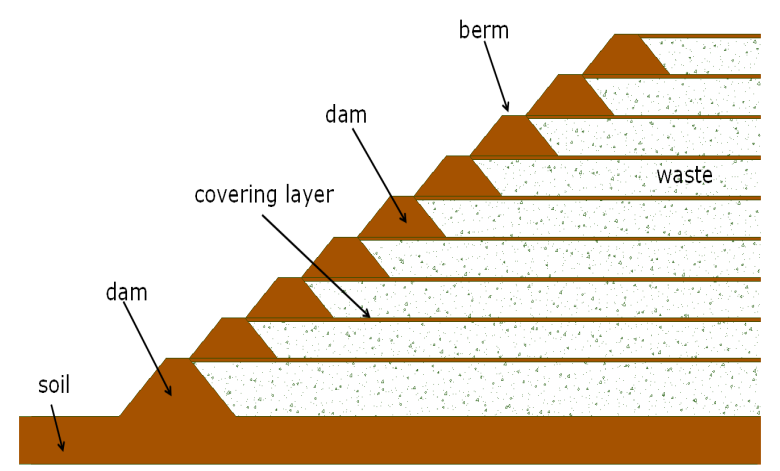

Figure 1. Representation of the section of the construction of the outer slope of a landfill.

The mechanical properties of the soil (bedrock) and the dam in the base are: $\gamma=2.0 \mathrm{t} / \mathrm{m}^{3}, \mathrm{C}^{\prime} \mathrm{o}=5 \mathrm{t} / \mathrm{m}^{2}$ and $\Phi^{\prime}=25^{\circ}$.
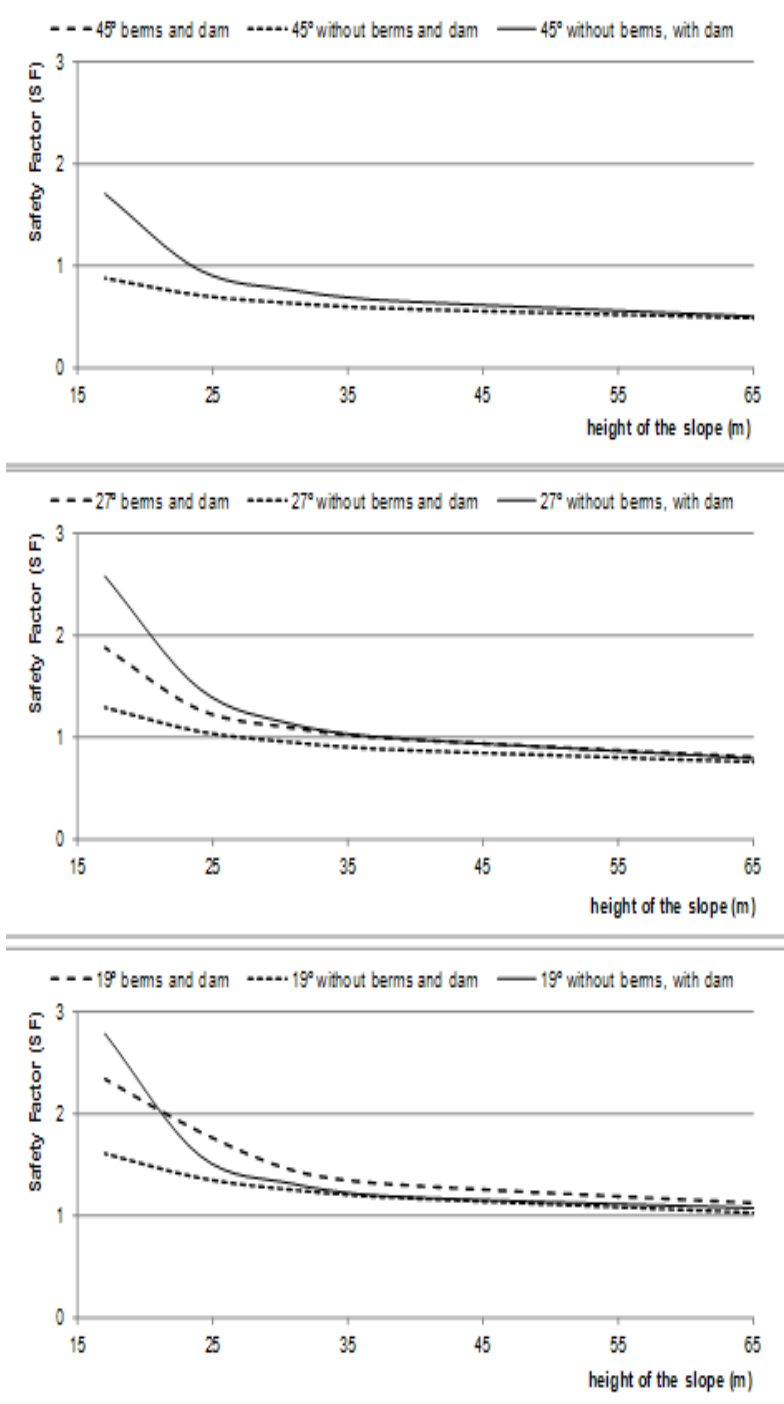

The seismic coefficient is nil. Calculations vary in height (H) and the width of the berms. The inclination of the slopes of earth dam downstream are always taken equally $\left(\rho=45^{\circ}\right)$, which provides different overall slope inclinations $(\beta)$.

In the second set of diagrams (Figures 3, 4 and 5), in order to estimate the mechanical properties of the wastes, three hypotheses have been made according to data provided by Table 1 : low values $\left(\mathrm{C}^{\prime} \mathrm{o}=1 \mathrm{t} / \mathrm{m}^{2}\right)$, medium values $\left(\mathrm{C}^{\prime} \mathrm{o}=2 \mathrm{t} / \mathrm{m}^{2}\right)$ and hight values $\left(\mathrm{C}^{\prime} \mathrm{o}=3 \mathrm{t} / \mathrm{m}^{2}\right)$. The values of effective friction angle are $\Phi^{\prime}=10^{\circ}, 15^{\circ}, 20^{\circ}$ and $25^{\circ}$. The density is $\gamma=0.9 \mathrm{t} / \mathrm{m}^{3}$. The mechanical properties of the soil (bedrock) and the dam in the base have been: $\gamma=2.0$ $\mathrm{t} / \mathrm{m}^{3}, \mathrm{C}^{\prime} \mathrm{o}=5 \mathrm{t} / \mathrm{m}^{2}$ and $\Phi^{\prime}=25^{\circ}$. The seismic coefficient is nil. So, graphics have been made for each of these cases of calculation. Thus, for each inclination and/or height of the slope, SF can be calculated with the dam $10 \mathrm{~m}$ high at the base and without it. In this sense, 672 sliding circles have been calculated and their corresponding SF. These data are plotted in Figures 3, 4 and 5.
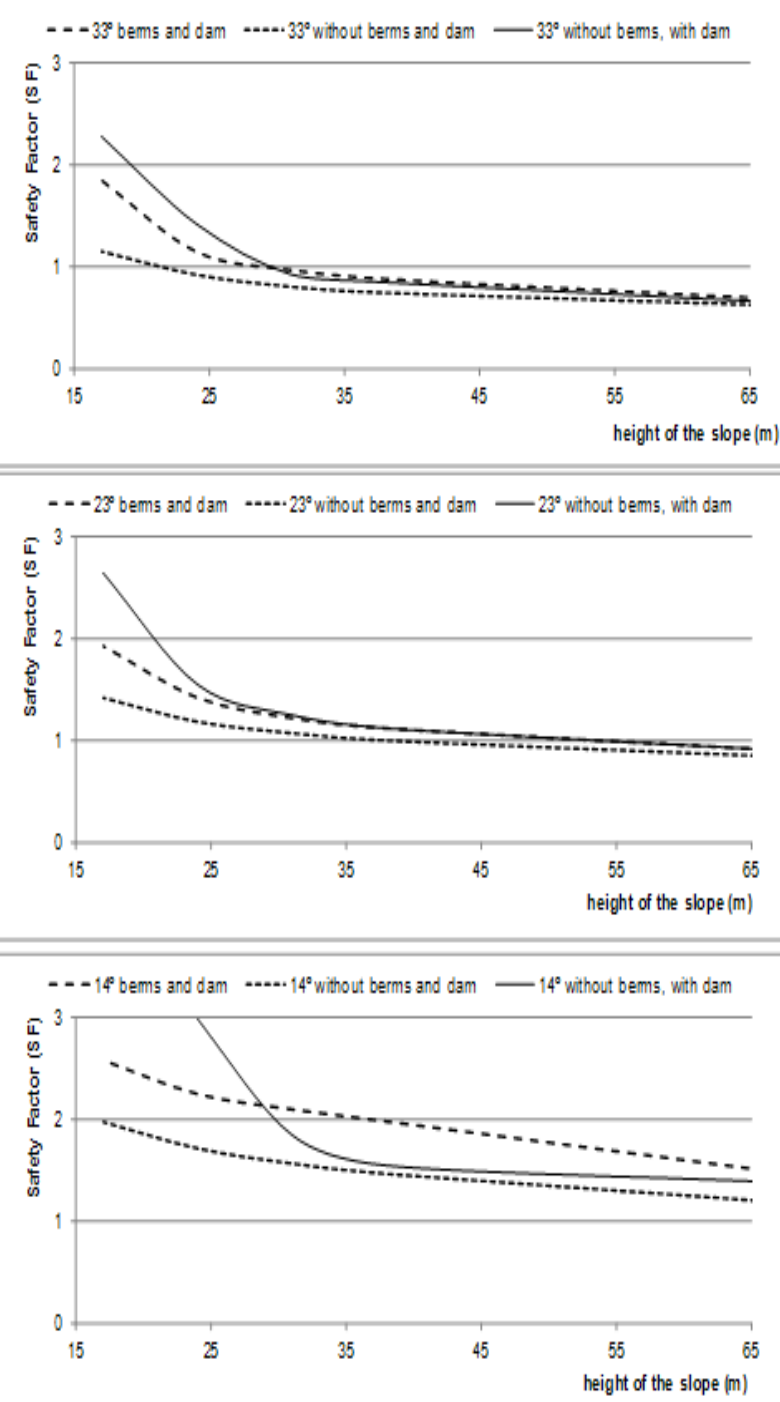

Figure 2. Variation of SF according to inclination and height of the slope. 


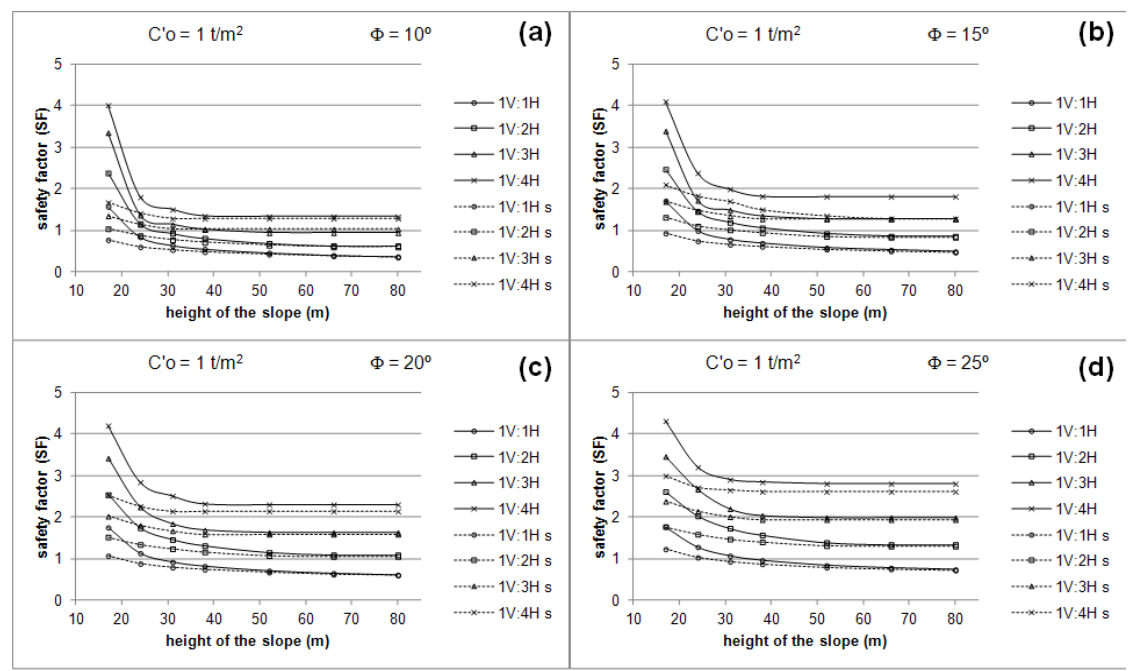

Figure 3. Relationship between the height of the slope and SF for values of effective cohesion $C^{\prime} \mathrm{o}=1 \mathrm{t} / \mathrm{m}^{2}$ (s: without dam at the bottom).

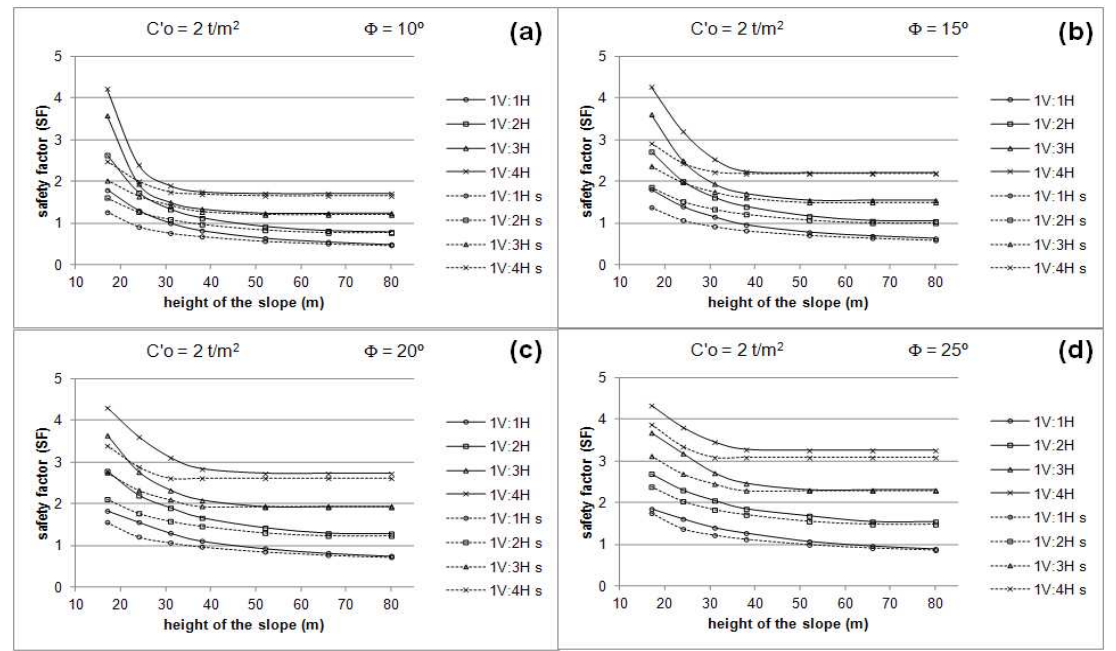

Figure 4. Relationship between the height of the slope and SF for values of effective cohesion $C^{\prime} \mathrm{o}=2 \mathrm{t} / \mathrm{m}^{2}$ (s: without dam at the bottom).

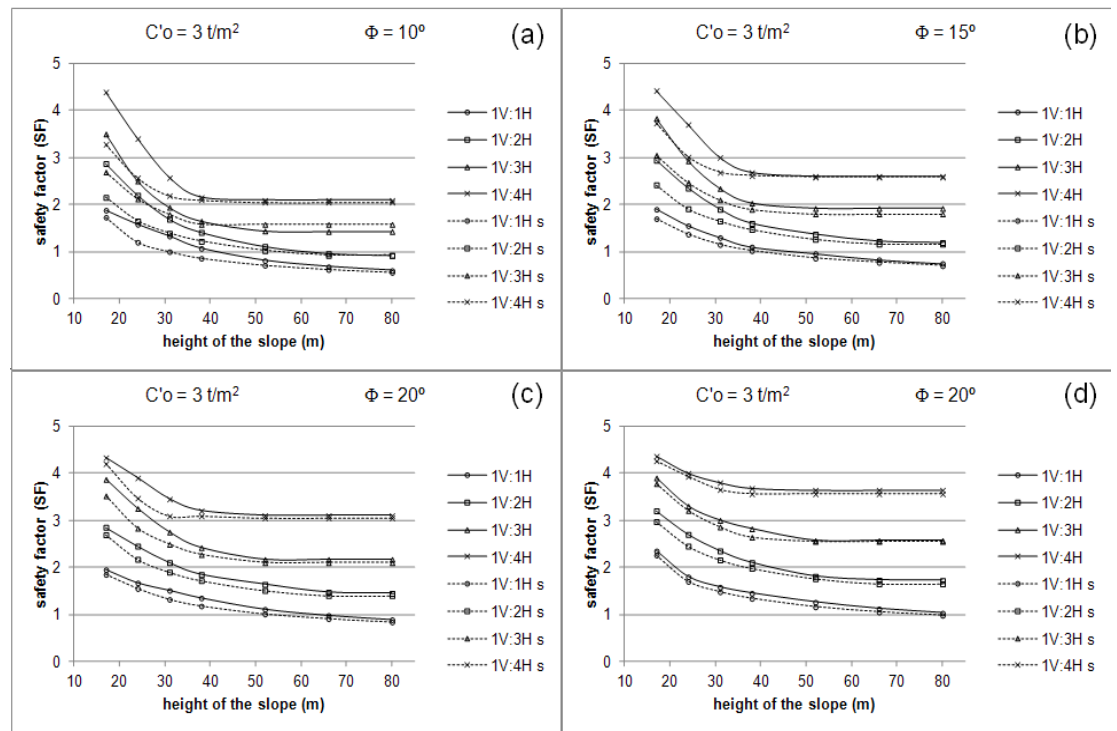

Figure 5. Relationship between the height of the slope and $S F$ for values of effective cohesion $C^{\prime} \mathrm{o}=3 \mathrm{t} / \mathrm{m}^{2}$ (s: without dam at the bottom). 


\section{Results}

In Figures 3, 4 and 5, the interdependence between SF and slope height is shown. Therefore, if the mechanical properties of the waste and the geometry of the slope (width of the berms, inclination, etc.) are known, the safe height of a landfill slope can be calculated.

\section{Discussion}

According to Feng and Gao [13] the landfill can be divided into three discrete parts: an active wedge lying on the back slope (resting on either liner surface or previously placed waste) that tends to cause failure, a passive wedge lying on the landfill's foundation soil or liner system that tends to resist failure and a retaining wall at the toe berm of the landfill that improves the stability of the waste mass. From the analysis of the above figures it seems that waste in landfills with poor mechanical properties and low heads, with the construction of a dam at the bottom it greatly improves SF, for any inclination of the slope. The better the mechanical properties are, the less influence. However, at the high point of the slope, the influence of the dam decreases, so that with high slopes, there is no positive influence of the dam on the SF. Furthermore, the presence of berms on the slope does not significantly influence the SF, although construction of berms allows machinery access to the working face, so it is advisable to build them.

The greater the height of the slope, the lower the FS, so that a $17 \mathrm{~m}$ high slope has a SF value 50\% larger than a 66 $\mathrm{m}$ high one, regardless of the inclination. Moreover, the smaller the slope, the greater is the FS, so that a slope of $1 \mathrm{~V}: 4 \mathrm{H}\left(14^{\circ}\right)$ has a SF value $60 \%$ larger than one of $1 \mathrm{~V}: 1 \mathrm{H}$ $\left(45^{\circ}\right)$.

The validation of this set of diagrams can be done by comparing the values of SF that provide conventional methods such as Janbu, corrected Janbu, Bishop and software professor Rechea. To do this, three slopes of different landfills have been analyzed (Figure 6 and Table 2).

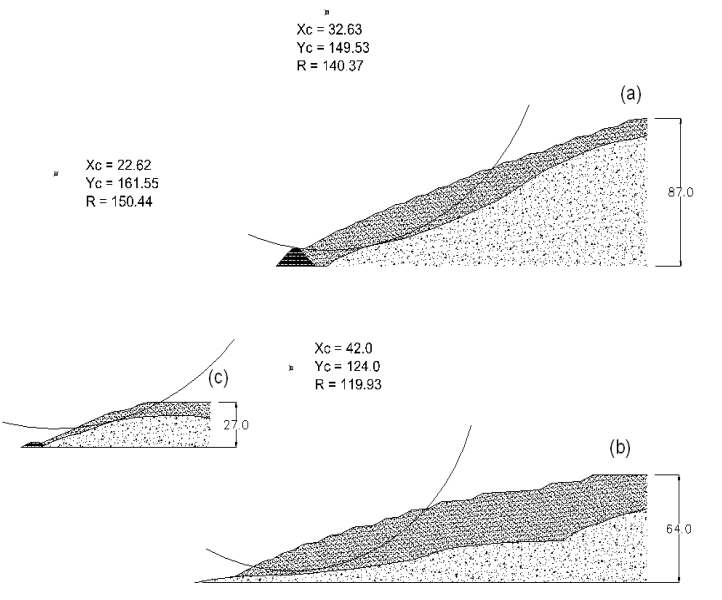

Figure 6. Graphical representation of three sections of different landfills.

Table 2. SF calculation using traditional methods compared with results obtained using the set of diagrams.

\begin{tabular}{|c|c|c|c|c|c|c|}
\hline & $\begin{array}{l}\text { SF Janbú } \\
\text { corrected }\end{array}$ & $\begin{array}{l}\text { SF simplified } \\
\text { Janbu }\end{array}$ & SF Bishop & SF Fellenius & SF Software & SF diagrams \\
\hline \multicolumn{7}{|l|}{$\begin{array}{l}\text { (a) } \\
\beta=20.5^{\circ}\end{array}$} \\
\hline $\begin{array}{l}C^{\prime}{ }^{\prime}=1.6 \\
\Phi^{\prime}=22 \\
\gamma=0.88\end{array}$ & 1.558 & 1.484 & 1.573 & 1.521 & 1.61 & 1.55 \\
\hline \multicolumn{7}{|l|}{ (b) } \\
\hline \multicolumn{7}{|l|}{$\beta=14.3^{\circ}$} \\
\hline $\begin{array}{l}C^{\prime} \mathrm{o}=1.1 \\
\Phi^{\prime}=16\end{array}$ & 1.411 & 1.338 & \multicolumn{3}{|c|}{$\Phi^{\prime}=16$} & 1.38 \\
\hline \multicolumn{7}{|l|}{$\gamma=0.81$} \\
\hline \multicolumn{7}{|l|}{ (c) } \\
\hline \multicolumn{7}{|l|}{$\beta=17.6^{\circ}$} \\
\hline $\mathrm{C}^{\prime} \mathrm{O}=2,0$ & 2.892 & 2.781 & 2.828 & 2.815 & 2.85 & 2.16 \\
\hline$\Phi^{\prime}=11$ & & & & & & \\
\hline$\gamma=0.85$ & & & & & & \\
\hline
\end{tabular}

On the other hand, a literature search on accidents occurred in landfills in recent years has been done. Among the accidents found three cases have been chosen, in which the lack of suitable design of the landfill slopes generated risks, which under specified conditions, led to accidents. After the accident, some trials, made by different engineers, were done in order to calculate an approximation of SF of the slopes.

The Sarajevo landfill (Bosnia-Herzegovina. December 1977): The slope was $50 \mathrm{~m}$ and had an inclination of $45-$ $60^{\circ}$. Mechanical properties of waste analyzed were $C^{\prime} \mathrm{o}=3$ $\mathrm{t} / \mathrm{m}^{2}$ and $\Phi^{\prime}=20-25^{\circ}$ which gave a SF of 1.1 , which is a very low value (Figure 7a). An explosion of gas contributing to slipping [9, 47, 48]. In the diagram (Figure 5c-5d), it is apparent that the geometry of the slope with these data 
provide a similar value.

The Hiriya landfill (Tel-Aviv, Israel. Jan. 1998): The top of the slope had a height of $60 \mathrm{~m}$ at an angle of $40^{\circ}$ at the bottom, but $56^{\circ}$ at the upper-end (Figure $7 \mathrm{~b}$ ). Mechanical properties of waste analyzed in landfill were $C^{\prime} \mathrm{o}=3 \mathrm{t} / \mathrm{m}^{2}$ and $\Phi^{\prime}=25^{\circ}$. The SF of the slope was 1.05 , a very unsafe value [38]. In this case, it is not possible to compare the data with the diagrams, as it assumes a uniform slope inclination. However, if taking the total inclination as $45^{\circ}$, as shown in Figure $5 \mathrm{c}$, it can be seen that the slope for the geometrical data with a $C^{\prime} \mathrm{o}=3 \mathrm{t} / \mathrm{m}^{2}$ and $\Phi^{\prime}=25^{\circ}$ would provide a similar value.

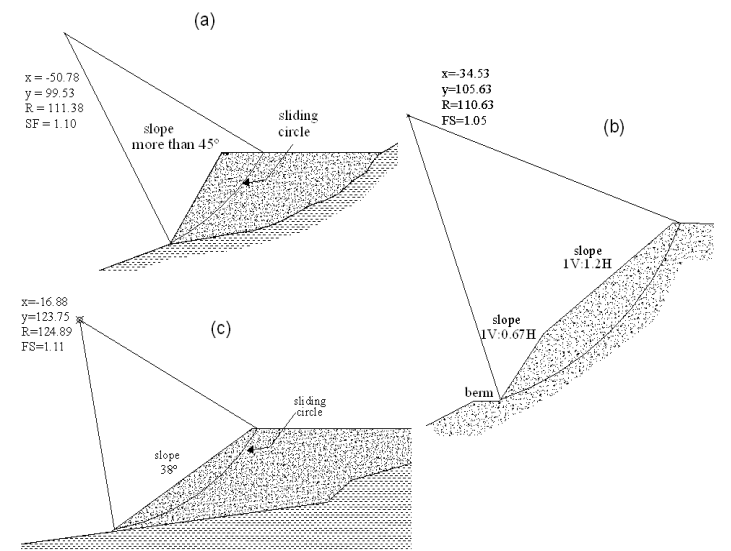

Figure 7. Representation of landfills in which an accident occurred. (a) Sarajevo, (b) Hiriya and (c) Bandung.

The Bandung landfill (Indonesia. February 2005): Torrential rain caused the formation of leachate that saturated the waste mass. The rain also infiltrated into the ground and damaged its mechanical properties, so that the mass of waste slid. Furthermore, a fire occurred in the landfill affecting cohesion and the friction angle of the waste, decreasing FS. The analyzed mechanical properties of the waste, according to authors, were $C^{\prime} \mathrm{o}<1 \mathrm{t} / \mathrm{m}^{2}$ and $\Phi^{\prime}<14^{\circ}$ because the waste was saturated due to the rainfall. A landfill without any design, over $60 \mathrm{~m}$ high and with a slope inclination between $30-45^{\circ}$ with a $\mathrm{FS}=1.13$ produced the catastrophe $[4,20]$. In this case, the value of SF provided by the authors is equivalent to that obtained in Figure 4c, but in this case, the waste mass was saturated, therefore the mechanical properties would have been even worse, and therefore, according to Figure $3 \mathrm{a}-3 \mathrm{~b} \mathrm{SF}<1$.

The mandatory first step in the design of a landfill is to comply with regulations. In terms of design, regulations in Canada require a minimum slope of $1 \mathrm{~V}: 4 \mathrm{H}\left(14^{\circ}\right)$, with this inclination a stable slope is ensured even at heights above $60 \mathrm{~m}$, saturation conditions and seismic coefficients higher than 0.15 . However, not all regulations oblige because most states either require only stable slopes (Philippines, European Union, Japan or India) or are limited to a maximum inclination 1V:3H (18.4 ) (Chile, Australia or South African Republic). These slopes, under normal conditions remain stable even at high gradient.

The calculations were performed with very adverse con- ditions in terms of the mechanical properties of the waste mass, and taking $C^{\prime} o$ values close to 0 and $\Phi^{\prime}$ minimal. As proof of this, slopes of landfills around $1 \mathrm{~V}: 2.5 \mathrm{H}\left(21.80^{\circ}\right)$ remain stable for a long time, even under conditions of heavy rainfall. So, presumably $C^{\prime} o$ values and $\Phi$ ' in the waste mass are significantly larger and provide sufficient stability to the slopes, where leachate and biogas are evacuated conveniently.

Evaluation of MSW shear strength parameters has received increasing attention in recent years. The expansion of old, poorly controlled landfills and the construction of new increasingly higher landfills, in an attempt to extend the lifespan of these structures, has led to the occurrence of numerous fatalities. It is often the unknown aspects of the mechanical behavior of undrained waste which figure among the possible causes of these events [40].

Thus, the set of diagrams presented in this paper provide information about the SF of a landfill slope in a fast and simple way. For this, it is necessary to know the slope geometry and mechanical properties of the waste. If these data are not available, it is desirable to take the most unfavorable cases, i.e., the diagram of Fig 4a. Furthermore, it would also be possible to know the inclination and the height at which a slope has an acceptable SF.

\section{Conclusions}

The set of diagrams shown in this paper are a suitable tool for calculating the SF of the slopes of landfills quickly. They do not need complicated calculations or computer programs. It is only necessary to know the mechanical properties. If the mechanical properties are available, a very accurate value for SF can be obtained and this value is always safer than that calculated using traditional methods. Every diagram allows the inclination of the slope in a landfill to be optimized.

\section{Acknowledgements}

The authors are grateful to the Spanish Ministry of Economy and Competitivenes for funding this study (Project ACI2009-0993) in the program "Convocatoria de Ayudas del Programa Nacional de Internacionalización de la I+D. Subprograma de Fomento de la Cooperación Científica Internacional (ACI-PROMOCIONA)".

\section{References}

[1] A. Allen, "Containment landfills: the myth of sustainability", Engineering Geology, vol. 60, pp. 3-19, 2001.

[2] L. F. Díaz, and G. M. Savage, "Developing landfill. Guidelines for sites in developing countries". Waste Management World ISWA. 2.J. Clerk Maxwell, A Treatise on Electricity and Magnetism, 3rd ed., vol. 2. Oxford: Clarendon, 1892, pp. 68-73, 2002.

[3] S.M. Merry, E. Kavazanjian, and W.U. Fritz, "Field Re- 
connnaisance of the July 10, 2000 Payatas Waste Slide, Quezon City, Phillipines", Journal of Performance of Constructed Facilities (ASCE), vol. 19( 2), pp. 100-107, 2005.

[4] F. Kölsch, K. Fricke, C. Mahler, E. Damanhuri, "Stability of landfills - the Bandung dumpsite disaster", Proceedings Sardinia 2005. International Waste Management and Landfill Symposium. S. Margherita di Paula, Cagliari, Italy. 2005.

[5] H. T. Eid, T. Stark, W. D. Evans, and P. E. Sherry, Municipal solid waste slope failure I: waste and foundation soil properties. Geotechnical and Geoenvironmental Engineering, vol. 126, pp. 397-407, 2000.

[6] R.M. Koerner, and T.-Y. Soong, "Leachate in landfills: the stability issues". Geotextiles and Geomembranes, vol. 18, pp. 293-309, 2000.

[7] E. Kavazanjian, "Seismic design of solid waste containment facilities. In: Proceedings of Eighth Canadian Conference on Earthquake Engineering. Vancouver, BC. 1999.

[8] B.Garabaghi, M.K. Singh, C. Inkratas, I.R. Fleming, and E. McBean, "Comparison of slope stability in two Brazilian municipal landfills", Waste Management, vol. 28, pp. 15091517,2008

[9] G. Blight, "Slope failures in municipal solid waste dumps and landfills: a review", Waste Management and Research, vol. 26, pp. 448-463, 2008.

[10] J. Jianguo, Y. Yong, Y. Shihui, Y. Bin, and Z. Chang, "Effects of leachate accumulation on landfill stability in humid regions of China", Waste Management, vol. 30, pp. 848-855, 2010.

[11] L. Yu, F. Batlle, "A hybrid method for qua-si-threedimensional slope stability analysis in a municipal solid waste landfill”, Waste Management, vol. 31, pp. 2484-2496, 2011.

[12] D. Choudhury, and P. Savoikar, "Equivalent-linear seismic analyses of MSW landfills using DEEPSOIL". Engineering Geology, vol. 107, pp. 98-108, 2009.

[13] S.-J. Feng, L.-Y. Gao, "Seismic analysis for translational failure of landfills with retaining walls", Waste Management, vol. 30, pp. 2065-2073, 2010.

[14] N. Dixon, and D.R.V. Jones, "Engineering properties of municipal solid waste". Geotextiles and Geomembranes, vol. 23, pp. 205-233, 2005.

[15] R.A. Siegel, R.J. Robertson, and D.C. Anderson, "Slope stability investigations at a landfill in southern California". Geotechnics of Waste Fills, Theory and Practice. ASTM STP 1070. Arvid Landva, G. Knowles, editors, American Society for Testing and Materials. Philadelphia, 1990.

[16] Earth Technology Corporation, "Instability of landfill slope, Puente Hills Landfill, Los Angeles County, California". Report to Los Ángeles County Sanitation District. Earth Technology Corporation, Los Ángeles, USA., 1988.

[17] S. Singh, and B. Murphy, "Evaluation of the stability of sanitary landfills. Geotechnics of Waste Fills, Theory and Practice". ASTM STP 1070. Arvid Landva, G. Knowles, editors, American Society for Testing and Materials. Philadelphia, 1990.

[18] H.L. Jessberger, "Geotechnical aspects of landfill design and construction. Part 2: material parameters and test methods", Geotechnical Engineering, Proceedings of the Institute of Civil Engineering, vol. 104, pp. 105-113, 1994.

[19] J. B. Fassett, G. A. Leonards, and P. C. Repetto, "Geotechnical properties of municipal solid wastes and their use in landfill design", Waste Technology '94, Landfill Technology, Technical Proceedings, Charleston, SC., 1994.

[20] F. Kölsch, "Material values for some mechanical properties of domestic waste", CISA (eds.): Proceedings of the Fifth International Landfill Symposium, Vol. 2, Cagliari (Italy), 1995.

[21] O. Del Greco, C. Oggeri, "Geotechnical parameters of sanitary wastes", Proceedings of the Fourth International Landfill Symposium, Sardinia, Italy, pp. 1421-1431, 1993.

[22] A.O. Landva, J.I. Clark, "Geotechnical testing of waste fill". Proceedings of the 39th Canadian Geotechnical Conference, Ontario, pp. 371-385, 1986.

[23] A.O. Landva, J.I. Clark, "Geotechnics of waste fill. Geotechnics of waste fills - theory and practice", ASTM STP 1079, pp 86-106, 1990.

[24] Golder Associates, Letter (November 24) to Patsy Goldberg, EPA, concerning the trail test results of the air stripper at the Hipps Road Landfill, with attached sample results. Golder Associates, Inc., Atlanta, GA, under contract to Waste Control of Florida, Inc., 1993.

[25] I.S. Oweis, W.T. Mills, A. Leung, and J. Scarino, "Stability of Sanitary Landfills, Geotechnical Aspects of Solid Waste Management", Metropolitan Section, American Society of Civil Engineers, December, 1985.

[26] A.H. Dvinoff, and D.W. Munion, "Stability failure of a sanitary landfill". In: Fang HY (ed) International Symposium on Environmental Geotechnology, pp 26-34, 1986.

[27] A. Pagotto, and P. Rimoldi, "Design and Construction of a Geogrid Reinforced Embankment Over Waste Material", Proceedings of Geosynthetics 87, New Orleans, LA. 1987.

[28] Sadat International Inc, Universidad de los Andes, Arthur D, Little Inc. "Informe de Diagnóstico Geotécnico y Ambiental de las causas del deslizamiento en el Relleno Sanitario de Doña Juana". Departamento Técnico y Administrativo del Medio Ambiente DAMA. Bogotá Diciembre de 1997.- Revisión Enero de 1998.

[29] A. Drescher, D. Newcomb, and T. Heimdahl, "Deformability of Tire Shreds Final Report". Oce of Research Services, Minnesota Department of Transportation, Minnesota, 1999.

[30] H.Prinz, "Abriß der Ingenieurgeologie". Ferdinand Enke, Stuttgart, pp. 466, 1991.

[31] J. M. Sánchez-Alciturri, J. Palma, C. Sagaseta, and J. Canizal, "Three years of deformation monitoring at Meruelo landfill". Waste disposal by landfill - GREEN 3, Sarsby ed., A. A. Balkema, Rotterdam, The Netherlands, 365-371, 1995.

[32] H.D. Sharma, M.T. Dukes, and D.M. Olsen, "Field measurements of dynamic module and Poisson's ratios of refuse and underlying soils at a landfill site", A. Landva, G.D. Knowles (Eds.), Geotechnics of Waste Fills - Theory and Practice, ASTM STP 1070, American Society for Testing and Materials, Philadelphia, pp. 57-70, 1990. 
[33] W.N. Houston, S.L. Houston, J.W. Liu, A. Elsayed, and C.O Sanders, "In-situ testing methods for dynamic properties of MSW landfills". Geotechnical Special Publication, ASCE, vol. 54, pp. 73-82, 1995.

[34] A. Mazzucato, P. Somonini, and S. Colombo, "Analysis of Block Slide in a MSW Landfill”. Proc. Sardinia '99 Seventh International Waste Management and Landfill Symposium, CISA, Vol. III, pp. 537-544, 1999.

[35] E. Kavazanjian, and N. Jr., Matasovic, "Seismic Analysis of Solid Waste Landfills". Geoenvironment 2000. ASCE Geotechnical Special Publication No. 46, vol. 2, pp. 1066-1080, 1995.

[36] B. Caicedo, L. Yamin, E. Giraldo, and O. Coronado, "Geomechanical properties of municipal solid waste in Dona Juana sanitary landfill". In: Proceedings of the Fourth International Congress on Environmental Geotechnics, vol. 1, Brazil, pp. 177-182, 2002.

[37] P.J. Sabatini, L.M.Griffin, R. Bonaparte, R.D. Espinoza, and J.P. Giroud, "Reliability of state of practice for selection of shear strength parameters for waste containment system stability analyses", Geotextiles and Geomembranes, vol. 20, pp. 241-262, 2002.

[38] R. Isenberg, E.R. Peterson, and R.H. Stenberg, "From landfill to leisure. Closure and rehabilitation of the Hiriya Landfill". Waste Management World, pp. 45-53, Sept-Oct 2004.

[39] K.R. Reddy, H. Hettiarachi, N.S. Parakalla, and J. Gangathulasi, "Geotechnical properties of fresh municipal solid waste at Orchard Hills Landfill, USA", Waste Management, vol. 29, pp. 952-959, 2009.
[40] N. Shariatmadari, S. Lemos Machado, A. Noorzad, M. Karimpour-Fard, "Municipal solid waste effective stress analysis". Waste Management, vol. 29, pp. 2918-2930, 2009.

[41] P. Hyun, P. Borinara, and K.D. Hong, "Geotechnical Considerations for End-Use of Old Municipal Solid Waste Landfills". International Journal of Environmental Research, vol. 5(3), pp. 573-584, 2011.

[42] F.J. Colomer, A. Ferrer, A. Gallardo, "Legislación sobre vertederos en algunos países del mundo. Análisis comparativo". II Congreso Ibérico sobre vertederos, Málaga, 2005.

[43] Bureau of Reclamation, "Manual de Tierras". Ed. Bellisco. Madrid, 1980.

[44] T. W. Lambe, and R. V. Whitman, "Mecánica de suelos (Nueva edición)”. Ed. Limusa. Mexico. 1990.

[45] F. Zapata, "Análisis del comportamiento histórico de balsas de tierra en la provincia de Alicante. Criterios de diseño", Doctoral Thesis, Universidad Politécnica de Valencia, 2003.

[46] SLOPE/W 2012. Copyright C 1995-2013 GEOSLOPE International Ltd. All Rights Reserved, 2012. http://www.geo-slope.com/products/slopew.aspx.

[47] ECONS S.A., Safety in landfill: photographic documentation. http://www.econs.ch/ Bioggio, Switzerland. 2003. www.econs.ch/file/safety_en.pdf consulted 1st Jan 2011.

[48] UNECE (United Nations Economic Commission for Europe), Management of waste and contaminated sites. Studies Bosnia Herzegovina. 6, 91-99. 2004. http://www.unece.org/fileadmin/DAM/env/epr/epr_studies/b osnia_and_herzegovina.pdf consulted 3rd March 2011. 